\title{
PENGEMBANGAN EKONOMI KREATIF UNTUK MENINGKATKAN PENDAPATAN MASYARAKAT DESA TANJUNGPAKIS KECAMATAN PAKISJAYA KABUPATEN KARAWANG
}

Oleh :

\author{
Dr. Budi Rismayadi, SE.,MM \\ Universitas Buana Perjuangan Karawang \\ Penulis Korespondensi : wanta@ubpkarawang,acid
}

\begin{abstract}
ABSTRAK
Peranan penting adanya penyuluhan terhadap upaya meningkatkan keahlian masyarakat petani dan nelayan di pedesaan merupakan tujuan yang ingin dicapai. Melalui penyuluhan masyarakat mendapatkan informasi dan wawasan, sehingga masyarakat dapat memahami secara mendalam tentang ekonomi kreatif serta manfaatnya bagi peningkatan pendapatannya. Materi penyuluhan yang disampaikan disesuaikan dengan potensi sumberdaya yang ada di desa. Materi penyuluhannya antara lain pemahaman mengenai apa yang dimaksud dengan ekonomi kreatif dan definisinya, mencakup apa itu kreatifitas, bagaimana memanfaatkan bahan baku local yang dapat di proses menjadi produk, proses pengolahan tempurung kelapa menjadi produk hiasan, produk-produk olahan dari udang dan ikan menjadi terasi, teknik pengemasan dan pemasaran terasi, mengingat desa Tanjungpakis sudah terkenal sebagai produsen terasi jembret yang cukup dikenal oleh warga Karawang. Kegiatan penyuluhan untuk penguatan ekonomi kreatif berbasis sumberdaya desa dapat memberikan manfaat yang besar bagi masyarakat. Hal ini terlihat dari antusiasnya masyarakat dalam mengikuti kegiatan penyuluhan dan dari tanya jawab juga tampak bahwa masyarakat merasa termotivasi untuk mengembangkan kreatifitas usahanya, demikian juga masyarakat yang hanya mengandalkan pekerjaannya sebagai petani dan nelayan tampaknya cukup tertarik untuk mencoba memulai mengembankan usaha kreatifitasnya
\end{abstract}

Kata Kunci : Penyuluhan, Sumberdaya, Ekonomi Kreatif

\section{PENDAHULUAN}

Kabupaten Karawang Dengan luas wilayah 1.753,27 km2 atau 3,73 persen dari luas Provinsi Jawa Barat, Karawang merupakan salah satu daerah yang memiliki lahan subur di Jawa Barat, sehingga sebagian besar lahannya digunakan untuk pertanian sawah dengan luas areal 97.529 Hektar, dan untuk perkebunan seluas 7.798 Hektar. Bentuk tanah di Kabupaten Karawang sebagian besar berbentuk dataran yang relatif rata dengan variasi antara $0-5 \mathrm{~m}$ di atas permukaan laut. Hanya sebagian kecil wilayah yang bergelombang dan berbukit-bukit dengan ketinggian antara $0-1200 \mathrm{~m}$ di atas permukaan laut.

Wilayah Kabupaten Karawang sebagian besar tertutup dataran pantai yang luas yang terhampar di bagian pantai Utara dan merupakan batuan sedimen yang dibentuk oleh bahan-bahan lepas, terutama endapan laut dan aluvium vulkanik. Di bagian tengah ditempati oleh perbukitan, terutama dibentuk oleh batuan sedimen, sedangkan di bagian Selatan terletak Gunung Sanggabuana 
serta memiliki kawasan pesisir yang sangat potensial untuk berbagai opsi pembangunan yaitu dengan tujuan akhir dari pembangunan adalah untuk kesejahteraan masyarakat sekitarnya. Sedangkan kecenderungan kerusakan lingkungan sering disebabkan oleh pembangunan yang selama ini diterapkan belum sesuai dengan prinsip-prinsip pembangunan berkelanjutan (sustainable development). Karena itu pembangunan yang bersifat partisipatif sangat penting untuk meningkatkan ekonomi masyarakat setempat. Terutama untuk mencapai tujuan-tujuan pengelolaan sumberdaya wilayah pesisir secara terpadu dan berkelanjutan, perlu penyeimbangan pengelolaan dengan multidimensi yakni dimensi ekologis, dimensi sosial, dimensi ekonomi, antar sektoral, disiplin ilmu dan segenap pelaku pembangunan (stakeholders).

Berdasarkan registrasi penduduk tahun 2013 jumlah penduduk Kabupaten Karawang 2.273.529 jiwa yang terdiri dari 1.166.478 laki-laki atau mencapai komposisi terbanyak hingga mencapai 51,31\% dan jumlah perempuan sebanyak 1.107.101 dengan komposisi sebesar 48,69\%, dengan sex ratio mencapai 105,36. Sedangkan kepadatan rata rata mencapai 1.094 jiwa per $\mathrm{Km}^{2}$. Wilayah yang paling padat penduduknya adalah Kecamatan Karawang Barat dengan jumlah penduduk sebanyak 4.932 jiwa per $\mathrm{Km}^{2}$, sedangkan kecamatan dengan kepadatan penduduk paling rendah adalah Kecamatan Ciampel dengan rata rata jumlah penduduk mencapai 382 jiwa per $\mathrm{Km}^{2}$.

Selain itu komposisi penduduk juga dapat dilihat dengan mengelompokkan penduduk kedalam usia produktif $(15$ - 64 tahun), usia belum produktif (< 15 tahun) dan usia tidak produktif lagi ( $>65$ tahun) penduduk usia produktif merupakan modal dalam pelaksanaan pembangunan di segala sector, dengan harapan produktivitas dan efektivitas yang terjadi ditunjang pula dengan sarana dan prasarana yang memadai, dimana manusia menjadi tujuan dari pelaksanaan pembangunan itu sendiri. Penduduk usia produktif di Kabupaten Karawang pada tahun 2015 mencapai 1.555.595 orang atau sebesar 68,42\%. Sedangkan penduduk yang belum produktif mencapai 614.086 atau 27,01\% dan penduduk yang tidak produktif lagi sebanyak 103.898 orang atau sebesar 4,57\% dengan demikian rasio ketergantungan usia kurang dari 15 tahun dan penduduk usia lebih dari 65 tahun mencapai 46,15\% yang berarti bahwa setiap 100 orang penduduk usia produktif menanggung sebanyak 46 orang usia belum dan tidak produktif yaitu sekitar $51,61 \%$ sisanya $48,39 \%$ merupakan penduduk produktif dari laki-laki.

Penyebaran penduduk di Kabupaten Karawang tetap berpusat di wilayah tengah, karena memang sektor perekonomian juga masih berpusat di wilayah tersebut. Wilayah yang dilalui atau berdekatan dengan sarana/infrastruktur jalan tol atau kereta api, memiliki kepadatan penduduk yang lebih tinggi, seperti Kecamatan Karawang Barat, Karawang Timur, Telukjambe Timur jika dibandingkan dengan kecamatankecamatan lainnya. 
Tabel 1.

Jumlah Penduduk Kabupaten Karawang

Menurut Kecamatan Dan Jenis Kelamin Tahun 2015

\begin{tabular}{|c|c|c|c|c|}
\hline No & KECAMATAN & LAKI-LAKI & PEREMPUAN & JUMLAH \\
\hline 1 & PANGKALAN & 19.249 & 18.781 & 38.030 \\
\hline 2 & TEGALWARU & 18.941 & 17.909 & 36.850 \\
\hline 3 & CIAMPEL & 20.975 & 21.480 & 42.455 \\
\hline 4 & TELUKJAMBE TIMUR & 71.867 & 64.726 & 136.593 \\
\hline 5 & TELUKJAMBE BARAT & 26.178 & 25.476 & 52.654 \\
\hline 6 & KLARI & 84.945 & 82.666 & 167.611 \\
\hline 7 & CIKAMPEK & 59.040 & 56.431 & 115.471 \\
\hline 8 & PURWASARI & 34.510 & 33.765 & 68.275 \\
\hline 9 & TIRTAMULYA & 24.319 & 23.452 & 47.771 \\
\hline 10 & JATISARI & 39.682 & 38.008 & 77.690 \\
\hline 11 & BANYUSARI & 28.038 & 27.003 & 55.041 \\
\hline 12 & KOTABARU & 66.080 & 63.083 & 129.163 \\
\hline 13 & CILAMAYA WETAN & 41.970 & 39.291 & 81.261 \\
\hline 14 & CILAMAYA KULON & 33.203 & 31.295 & 64.498 \\
\hline 15 & LEMAHABANG & 33.602 & 31.953 & 65.555 \\
\hline 16 & TELAGASARI & 33.514 & 31.396 & 64.910 \\
\hline 17 & MAJALAYA & 24.367 & 23.123 & 47.490 \\
\hline 18 & KARAWANG TIMUR & 66.162 & 61.145 & 127.307 \\
\hline 19 & KARAWANG BARAT & 85.784 & 81.965 & 167.749 \\
\hline 20 & RAWAMERTA & 27.045 & 25.452 & 52.497 \\
\hline 21 & TEMPURAN & 32.601 & 30.632 & 63.233 \\
\hline 22 & KUTAWALUYA & 30.185 & 27.794 & 57.979 \\
\hline 23 & RENGASDENGKLOK & 57.737 & 55.008 & 112.745 \\
\hline 24 & JAYAKERTA & 33.589 & 31.066 & 64.655 \\
\hline 25 & PEDES & 39.057 & 36.648 & 75.705 \\
\hline 26 & CILEBAR & 22.045 & 20.864 & 42.531 \\
\hline 27 & CIBUAYA & 26.909 & 25.593 & 52.502 \\
\hline 28 & TIRTAJAYA & 34.185 & 32.623 & 66.808 \\
\hline 29 & BATUJAYA & 40.719 & 40.575 & 81.294 \\
\hline 30 & PAKISJAYA & 19. 812 & 19.643 & 39.455 \\
\hline \multicolumn{2}{|r|}{ JUMLAH } & 1.177 .310 & 1.118 .468 & 2.295.778 \\
\hline
\end{tabular}

Sumber : BPS Kabupaten Karawang, 2016

Tingginya jumlah penduduk pada usia produktif merupakan suatu potensi sumberdaya manusia yang bisa mendukung kemajuan dan keberlanjutan pembangunan desa apabila diberdayakan secara maksimal. Kehidupan sosial ekonomi rumah tangga masyarakat dipesisir utara Kabupaten Karawang tidak jauh berbeda dengan karakteristik rumah tangga nelayan di kawasan pesisir pada umumnya dimana sebagian besar mereka masih tergolong dalam struktur sosial ekonomi berskala kecil, berorientasi subsisten serta berteknologi sederhana serta memiliki keterbatasan pendapatan, pendidikan dan keterampilan sehingga memiliki kecenderungan terhadap kondisi kemiskinan. Keuntungan-keuntungan ekonomi dari pemanfaatan 
sumberdaya sumberdaya pesisir (kelautan dan perikanan) yang terdapat disekitar mereka lebih didominasi oleh kelompok masyarakat tertentu yang memiliki modal seperti pemilik pemilik kapal dan pengusahapengusahan perikanan berskala menengah keatas. Aktifitas sosial ekonomi kelas menengah ini diperkirakan akan menimbulkan tingginya koefisien gini masyarakat dan terjadinya kesenjangan social dan ekonomi sehingga dikhawatirkan akan memunculkan permasalahan kesenjangan terutama bagi keberlanjutan mata pencaharian rumah tangga miskin berskala kecil.

Karena itu untuk keberlanjutan mata pencaharian rumah tangga miskin di kawasan pesisir perlu dicari peluang-peluang ekonomi kreatif yang berkelanjutan tanpa merusak sumberdaya alam di sekitarnya. Konsep mata pencaharian berkelanjutan diawali dari keinginan pemberdayaan kapasitas orang-orang yang membutuhkan penghasilan saat sekarang dan kebutuhan sosial ekonomi masa yang akan datang dan memperkecil kerentanan mereka terhadap tekanan dan goncangan (Ashley \& Carney, 1999). Sesuai dengan konsep tersebut maka sumberdaya alam yang terdapat di kawasan pesisir apabila bisa dimanfaatkan dan dikelola menggunakan prinsip-prinsip keberlanjutan maka diharapkan akan berdampak pada peningkatan kesejahteraan rumah tangga miskin di sekitarnya selain juga memiliki mata pencaharian alternatif dan berkelanjutan.

Kekayaan sumberdaya alam pesisir yang terdapat di sepanjang Pesisir Utara Kabupaten Karawang yang mencapai hingga sepanjang $84,23 \mathrm{Km}$, tentu dimanfaatkan sebagai sumber pendapatan masyarakat sebagian kecilnya adalah nelayan, jumlah perahu yang dimiliki para nelayan di Karawang tercatat sebanyak 1.323 buah perahu dengan mesin motor temple, sedangkan perahu bermotor hanya sebanyak 147 unit saja, dan sebagian besar matapencaharian masyarakat pesisir utara adalah petani tambak ikan air laut dan ikan air payau, mereka merupakan para petani tambak ikan bandeng, ikan mas dan udang galah, sebagian kecil mengembangkan budidaya rumput laut air payau, sedangkan luas areal tambak disepanjang pesisir utara Karawang berdasarkan data BPS Karawang tahun 2016 menunjukkan bahwa luas potensial tambak di Karawang adalah 17.608,8 Hektar sedangkan jumlah yang terpakai untuk areal tambak adalah seluas 14.012,20 Hektar, berarti masih terdapat lahan yang belum digunakan untuk areal tambak 3.596,6 Hektar.

Luas area terumbu Karang yang hanya terdapat di tiga kecamatan yaitu Cilamaya Wetan, Cilamaya Kulon dan Tempuran mencapai 2.091,47 Hektar, sebagian besar dari areal terumbu karang tersebut telah rusak 1.152,47 Hektar, seluas 889 Hektar kondisi sedang dan hanya tinggal 50 Hektar dengan kondisi baik, ini menujukkan bahwa kondisi biota laut di Karawang terancam rusak.

Luas areal mangrove di pesisir utara pada tahun 2016 berdasarkan data dari BPS Karawang mencapai luas 10.005,93 hektar, seluas 5.400,31 Hektar sudah dalam keadaan rusak, 3.948,96 dalam kondisi sedang dan tinggal 656,66 Hektar dalam kondisi yang masih baik, ini pun menunjukkan bahwa masyarakat 
pesisir Karawang tampaknya kurang begitu memperhatikan pelestarian hutan mangrove, sebagian besar areal hutan mangrove dijadikan sebagai tambak ikan oleh warga masyarakat.

Kecamatan Pakisjaya merupakan Kecamatan paling ujung di Kabupaten Karawang yang berbatasan dengan Kabupaten Bekasi, memiliki 8 desa dengan jumlah penduduk berdasarkan data BPS Karawang pada tahun 2016 sebanyak 39.455 jiwa. Kecamatan Pakisjaya merupakan daerah pesisir utara, memiliki areal pantai utara yang masuk dalam desa Tanjungpakis, potensi pantai utara di kecamatan pakisjaya memungkinkan untuk dikembangkan menjadi objek wisata pantai, namun hingga saat ini masih belum dikelola dengan baik mengingat perizinan mengenai objek wisata pantai belum sepenuhnya dapat dilaksanakan oleh pemerintah daerah setempat.

Desa Tanjungpakis merupakan desa terluar di Kabupaten Karawang berada dipesisir utara dan berbatasan dengan Kabupaten Bekasi, jumlah penduduk desa berdasarkan data dari BPS Karawang dalam katalog Kecamatan Pakisjaya dalam Angka Tahun 2017 tercatat sebanyak 5.926 jiwa yang terdiri dari lakilaki sebanyak 2.583 jiwa dan perempuan sebanyak 2.583 jiwa. Banyaknya jumlah keluarga miskin penerima surat miskin sebanyak 2.773 dan kartu sehat sebanyak 976 orang. Luas lahan untuk kegiatan pertanian ladang/kebun/kolam/tambak di desa Tanjungpakis seluas 109,56 Hektar sedangkan untuk sawah basah berpengairan seluas 593 Hektar dan seluas 125 Hektar adalah sawah tidak berpengairan.

Banyaknya unit usaha kecil dan menengah yang ada di wilayah desa tanjungpakis berdasarkan data dari Badan Pusat Statistik Karawang menyebutkan bahwa jenis usaha kecil yang bergerak dibidang makanan dan minuman sebanyak 1 (satu) UMKM dan hanya menyerap sebanyak 4 (empat) orang tenaga kerja, unit usaha yang bergerak dibidang industry pakaian jadi sebanyak 2 (dua) UMKM dengan menyerap tenaga kerja sebanyak 8 (delapan) orang dan unit usaha industry kayu, barang olahan dari kayu, bamboo rotan dan sebagainya ada sebanyak 5 (lima) UMKM dengan menyerap tenaga kerja sebanyak 10 (sepuluh) orang, yang relative cukup banyak adalah unit usaha perdagangan dan restoran, dimana unit perdagangan memiliki sebanyak 96 unit usaha perdagangan dengan menyerap sebanyak 154 orang tenaga kerja, dan sector restoran sebanyak 20 unit dengan menyerap tenaga kerja sebanyak 43 orang, hal ini karena desa tanjungpakis memiliki potensi objek wisata pesisir pantai yang banyak dikunjungi wisatawan local.

Wilayah pesisir di Kecamatan Pakisjaya memiliki keterbatasan sumberdaya alam untuk dapat meningkatkan kesejahteraan masyarakat setempat, dibutuhkan banyak ide-ide kreatif dari masyarakat dalam pemanfaatan keterbatasan sumberdaya tersebut. Ide ide kreatif tersebut dapat dituangkan dalam bentuk produk-produk kreatif yang dapat meningkatkan kesejahteraan. Menurut ahli ekonomi Paul Romer (1993), ide adalah barang ekonomi yang sangat penting, lebih penting dari objek yang ditekankan di kebanyakan model-model ekonomi. Di dunia dengan keterbatasan fisik ini, adanya penemuan ide-ide besar bersamaan 
dengan penemuan jutaan ide ide kecil yang membuat ekonomi tetap tumbuh. Ide adalah instruksi yang membuat kita mengkombinasikan sumber daya fisik yang penyusunannya terbatas menjadi lebih bernilai.

Kemudian Alvin Toffler (1980) dalam teorinya melakukan pembagian gelombang peradaban ekonomi kedalam tiga gelombang. Gelombang pertama adalah gelombang ekonomi pertanian. Kedua, gelombang ekonomi industri. Ketiga adalah gelombang ekonomi informasi. Kemudian diprediksikan gelombang keempat yang merupakan gelombang ekonomi kreatif dengan berorientasi pada ide dan gagasan kreatif. Romer juga berpendapat bahwa suatu negara miskin karena masyarakatnya tidak mempunyai akses pada ide yang digunakan dalam perindustrian nasional untuk menghasilkan nilai ekonomi

Pendidikan yang terbatas bagi masyarakat desa tidak berarti mereka tidak memiliki ide-ide kreatif untuk meningkatkan ekonomi keluarganya, akan tetapi mereka belum memiliki motivasi yang tinggi untuk mengembangkan ide-ide kreatif tersebut serta masih rendahnya akses terhadap informasi, teknologi, pelatihan pelatihan keterampilan serta jaringan pemasaran hasil usahanya. Untuk itu perlu dilakukan penyuluhan terutama kepada masyarakat desa untuk menambah pengetahuan mengenai bagaimana mengembangkan ide-ide kreatif menjadi sumber-sumber ekonomi kreatif yang dapat meningkatkan pendapatan dan kesejahteraan masyarakat.

Berdasarkan pada latar belakang tersebut di atas, maka penulis memandang perlu untuk melaksanakan kegiatan penyuluhan bagi warga masyarakat pesisir utara khususnya di Desa Tanjung Pakis Kecamatan Pakisjaya Karawang dengan judul “ Penyuluhan Potensi Pengembangan Ekonomi Kreatif Desa Tanjungpakis Kecamatan Pakisjaya Kabupaten Karawang tahun 2015”

\section{RUMUSAN MASALAH}

Kabupaten Karawang memiliki potensi wilayah yang cukup strategis, dengan kekayaan sumberdaya alam yang belum dimanfaatkan secara optimal serta potensi sumberdaya manusia yang bisa mendukung ekonomi kreatif di pedesaan. Di sisi lain aktifitas sosial ekonomi yang selama ini dilakukan masyarakat desa belum mengarah dan berfokus pada penguatan ekonomi kreatif. Karena itu upaya mengeksplorasi sumberdaya manusia melalui pengembangan ide-ide kreatifnya diharapkan akan dapat menciptakan penguatan ekonomi kreatif di pedesaan serta meningkatkan kesejahteraan masyarakat. Untuk itu masyarakat desa perlu mendapatkan penyuluhan mengenai pemahaman mengenai ruang lingkup ekonomi kreatif dan pengetahuan bagaimana mengembangkannya di wilayah pedesaan.

Sesuai tujuan tersebut di atas perlu dilakukan kegiatan pemberdayaan masyarakat di pedesaan untuk menjawab beberapa pertanyaan berikut yaitu:

123. Buana Ilmu 
1. Apa saja potensi sumberdaya desa yang dapat dimanfaatkan oleh masyarakat mendukung ekonomi kreatif untuk tujuan peningkatan kesejahteraan?

2. Sejauhmana keinginan masyarakat untuk meningkatkan pendapatannya melalui optimalisasi pemanfaatan sumberdaya desa

\section{TUJUAN KEGIATAN}

Tujuan yang ingin dicapai dari kegiatan ini adalah:

1. Untuk memberikan penyuluhan mengenai ruang lingkup ekonomi kreatif dan bagaimana mengembangkan ide-ide kreatif menjadi sumber-sumber ekonomi kreatif di desa Tanjungpakis Kecamatan Pakisjaya

2. Untuk meningkatkan pengetahuan dan pemahaman masyarakat mengenai manfaat ekonomi kreatif dalam meningkatkan kesejahteraan dan perekonomian desa.

\section{MANFAAT KEGIATAN}

Dengan adanya kegiatan ini diharapkan dapat memberi kontribusi kepada masyarakat berupa :

1. Pengetahuan, wawasan serta motivasi untuk mengembangkan ide-ide kreatif menjadi usaha-usaha ekonomi kreatif di pedesaan

2. Masyarakat dapat meningkatkan pendapatan dan kesejahteraannya melalui pengembangan usaha ekonomi kreatif dengan mengoptimalkan pemanfaatan sumberdaya yang ada di desa

\section{TINJAUAN PUSTAKA}

Perkembangan ilmu pengetahuan yang terjadi saat ini cukup mampu memberikan tambahan informasi yang bias dijadikan sebagai dasar bagi setiap orang dalam meningkatkan kualitas hidup, salah satunya adalah dengan meningkatkan kreativitas diberbagai bidang yang dikehendaki.

Perkembangan teknologi informasi juga mampu memberikan wawasan dan inovasi sehingga mendorong setiap orang untuk dapat meningkatkan aktivitas dan kreativitas dalam menghasilkan berbagai temuan dan produk hasil inovasi, proses produksi hingga pengembangan produknya, hal ini menjadi salah satu factor yang menjadikan pentingnya pengetahuan mengenai ekonoi kreatif oleh setiap orang.

Pemikiran kita mengenai bagaimana upaya Peningkatan Kesejahteraan masyarakat melalui Ekonomi kreatif diyakini dapat memberikan kontribusi bagi perekonomian bangsanya secara signifikan. Indonesiapun mulai melihat bahwa berbagai subsektor dalam industri kreatif berpotensi untuk dikembangkan karena Indonesia kaya sumberdaya insan kreatif dan warisan budaya. 
Peran penting dari semakin berkembangnya ekonomi kreatif di Indonesia telah terbukti pasca krisis ekonomi yang melanda pada era tahun 1990 an hingga tahun 2000, ternyata ekonomi kreatif dapat tetap bertahan dan bahkan mampu menopang aktivitas ekonomi Indonesia dengan sangat baik, dan ini diyakini akan mampu menjawab persoalan ekonomi mendasar dalam tujuan meningkatkan pertumbuhan ekonomi Indonesia, mampu menyediakan lapangan pekerjaan bagi masyarakat sehingga menekan tingkat pengangguran terbuka di Indonesia, mampu memberikan tambahan pendapatan dan meningkatkan kemampuan beli masyarakat sehingga diharapkan dapat menekan angka kemiskinan masyarakat.

Daniel L.Pink (The Whole New Mind, 2005) mengungkapkan bahwa di era kreatifitas bila ingin maju kita harus melengkapi kemampuan teknologi kita (high-tech), dengan hasrat untuk mencapai tingkat "highconcept" dan "high-touch". High-concept adalah kemampuan menciptakan keindahan artistic dan emosional, mengenali pola-pola dan peluang, menciptakan narasi yang indah dan menghasilkan temuantemuan yang belum disadari orang lain. High-touch adalah kemampuan berempati, memahami esensi interaksi manusia dan menemukan makna (Departemen Perdagangan RI, 2008).

\section{METODE PELAKSANAAN}

\section{SASARAN}

Sasaran dari kegiatan penyuluhan ini adalah warga masyarakat Desa Tanjung Pakis Kecamatan Pakisjaya Kabupaten Karawang yang terdiri dari 50 orang Kepala Keluarga yang berminat terhadap pengembangan ekonomi kreatif di desa.

\section{LUARAN YANG DIHARAPKAN}

Luaran yang diharapkan dari kegiatan ini adalah:

1. Masyarakat menjadi termotivasi dan lebih percaya diri untuk mengembangkan dan mewujudkan ide-ide kreatif.

2. Masyarakat memahami pentingnya pengembangan ekonomi kreatif untuk meningkatkan pendapatan keluarga dan perekonomian desa.

3. Berkembangnya kegiatan ekonomi kreatif di desa untuk menunjang pembangunan di Desa Tanjungpakis

4. Terbentuknya kelembagaan desa yang mendukung pengembangan ekonomi kreatif di desa Tanjungpakis

\section{TEMPAT DAN TAHAPAN PELAKSANAAN}

125. Buana Ilmu 
Kegiatan pengabdian kepada masyarakat ini dilaksanakan di Desa Tanjungpakis Kecamatan Pakisjaya Kabupaten Karawang Propinsi Jawa Barat. Pelaksanaan pengabdian kepada masyarakat ini dilakukan selama 3 (tiga) bulan yaitu bulan Januari sampai dengan bulan Maret 2018 yang terdiri dari beberapa tahapan sebagai berikut:

1. Mempersiapkan bahan atau materi yang diperlukan pada penyuluhan penguatan ekonomi kreatif berbasis sumberdaya desa bagi masyarakat Desa Tanjungpakis Kecamatan Pakisjaya Kabupaten Karawang.

2. Mengadakan pertemuan sesama tim penyuluhan untuk mendiskusikan materi kegiatan yang akan dilaksanakan dan pembagian tugas antar tim pelaksana.

3. Mengadakan pertemuan dengan Kepala Desa Tanjungpakis Kecamatan Pakisjaya Kabupaten Karawang guna mendapatkan izin pelaksanaan dan penetapan jadwal kegiatan.

4. Mengadakan penyuluhan mengenai penguatan ekonomi kreatif berbasis sumberdaya desa di Desa Tanjungpakis Kecamatan Pakisjaya Kabupaten Karawang.

\section{HASIL DAN PEMBAHASAN}

Kegiatan ini terselenggara atas kerjasama dengan masyarakat dan aparat pemerintahan desa Tanjungpakis Kecamatan Pakisjaya Kabupaten Karawang dan dibantu oleh beberapa orang mahasiswa UBP Karawang tahun angkatan 2016. Kegiatan penyuluhan ini merupakan salah satu tahapan penting dari kegiatan penelitian dan pengabdian pada masyarakat sebagai bagian Tridarma Perguruan Tinggi yang dilaksanakan pada hari Senin tanggal 26 Maret 2018 mulai pukul 10.00 WIB hingga selesai. Penyuluhan dilakukan di Aula Kantor Desa Tanjungpakis Kecamatan Pakisjaya Kabupaten Karawang. Yang memberikan kata sambutan dalam penyuluhan ini adalah sekretaris camat Kecamatan Pakisjaya. Sedangkan sebagai narasumber pada kegiatan penyuluhan ini adalah :

1. Dr. Budi Rismayadi, SE.,MM, pendidikan terakhir adalah doctor ilmu manajemen, aktif dalam berbagai kegiatan penelitian dan pengabdian kepada masyarakat, pendiri beberapa forum dan komunitas di masyarakat baik bidang ekonomi dan social. Beberapa forum telah berkembang dengan cukup baik di Karawang antara lain adalah, komunitas Karawang Berkebun, Komunitas Pemuda Pecinta Lingkungan, Komunitas petani hidroponik Karawang, penggerak Posdaya Kabupaten Karawang, aktif dalam kegiatan pengelolaan sampah menjadi produk bernilai ekonomi.

2. Mumun Maemunah, SE.,MM. pendidikan terakhir magister Management untuk konsentrasi manajemen keuangan, aktif dalam kegiatan penelitian dan pengabdian masyarakat, mengelola 
beberapa usaha, aktif dalam Yayasan yang mengelola Panti Asuhan Anak dan selalu mengembangkan kreasi

3. Wanta, SE.,MM, pendidikan terakhir adalah magister management konsentrasi pada manajemen sumber daya manusia, aktif dalam kegiatan penelitian dan kegiatan pengabdian masyarakat, mengembangkan usaha kecil dan menengah, serta koperasi di Kabupaten Karawang.

Narasumber merupakan dosen Program Studi Manajemen Fakultas Bisnis dan Ilmu Sosial Universitas Buana Perjuangan Karawang. Selain memberikan ceramah pada penyuluhan tersebut, narasumber juga membagikan brosur usaha ekonomi kreatif. Kegiatan berlangsung lancar dan peserta mengikuti kegiatan dengan antusias dan bersemangat.

Dalam pelaksanaannya kegiatan penyuluhan ini dihadiri oleh berbagai lapisan masyarakat. Tokoh masyarakat yang hadir antara lain Bapak Camat Pakisjaya, Bapak Sekretaris Camat, Bapak kepala desa tanjungpakis beserta seluruh RT dan RW. Selain tokoh masyarakat juga dihadiri oleh ketua organisasi di masyarakat, ketua kelompok usaha, serta pengusaha-pengusaha kecil dan menengah. Masyarakat yang hadir tampak sangat antusias mendengarkan penyuluhan yang disampaikan, hal ini tampak dari banyaknya masyarakat yang bertanya dan ingin mendapatkan penjelasan lebih mendalam bagaimana ekonomi kreatif bisa mereka kembangkan di wilayah desa mereka.

Sebagai wujud nyata dari kegiatan pengabdian ini sebagai luarannya adalah terbentuknya "Rumah kreasi" yang dibangun atas kerjasama dengan masyarakat dan UBP Karawang. Secara legal pendirian "Rumah Kreasi” tersebut diresmikan oleh Bapak Camat Kecamatan Pakisjaya Kabupaten Karawang. Selanjutnya seluruh pengurus yang sudah dibuat surat keputusannya dilantik oleh bapak camat.

Harapan masyarakat Rumah Kreasi tersebut bisa bermanfaat untuk jangka panjang sehingga mereka sangat memerlukan bimbingan dari pihak-pihak berkompeten. Kegiatan penyuluhan dilakukan dengan metode ceramah, tanya jawab serta mempertontonkan film-film proses-proses pembuatan produk kreatif masyarakat pedesaan dari daerah lain. Pemutaran film ini juga bermaksud untuk memotivasi keinginan masyarakat untuk mengembangkan ide-ide kreatif yang dimiliki untuk memanfaatkan sumberdaya yang tersedia di wilayahnya. Potensi sumberdaya desa Tanjungpakis sangat beragam dan prospek dikembangkan untuk mendukung geliat ekonomi kreatif masyarakat, terlebih lagi desa Tanjungpakis memiliki objek wisata bahari yang banyak dikunjungi oleh para wisatawan baik dari Karawang maupun dari luar Karawang. Sumberdaya yang dapat mendukung ekonomi kreatif masyarakat antara lain sumberdaya pertanian padi dan palawija, sumberdaya perikanan (udang, ikan dan lain-lain), sumberdaya wisata (pantai, tempat bersejarah dan lainlain), sumberdaya adat istiadat, serta sumerdaya wisata bahari. Di sini memiliki tempat yang sangat menarik untuk dikembangkan sebagai upaya meningkatkan kesejahteraan. Sumberdaya yang terpenting yang dimiliki adalah sumberdaya manusia yang dimiliki desa untuk pengembangan ekonomi kreatif. 
Materi penyuluhan yang disampaikan disesuaikan dengan potensi sumberdaya yang ada di desa. Materi penyuluhannya antara lain pemahaman mengenai apa yang dimaksud dengan ekonomi kreatif dan definisinya, mencakup apa itu kreatifitas, bagaimana memanfaatkan bahan baku local yang dapat di proses menjadi produk, proses pengolahan tempurung kelapa menjadi produk hiasan, produk-produk olahan dari udang dan ikan menjadi terasi, teknik pengemasan dan pemasaran terasi, mengingat desa Tanjungpakis sudah terkenal sebagai produsen terasi jembret yang cukup dikenal oleh warga Karawang.

Selain dengan metode ceramah materi juga disampaikan dengan memutar video film proses pembuatan produk olahan kreatif tersebut. Sehingga masyarakat menjadi lebih cepat pemahamannya dan tertarik mengikuti penyuluhan hingga selesai. Kegiatan penyuluhan ini juga dipublikasikan di media massa lokal. Pelaksanaan penyuluhan yang diberikan kepada masyarakat sudah merupakan langkah tepat untuk memotivasi selera usaha masyarakat.

Peranan penting adanya penyuluhan terhadap upaya meningkatkan keahlian masyarakat petani dan nelayan di pedesaan merupakan tujuan yang ingin dicapai dalam kegiatan ini. Melalui penyuluhan masyarakat mendapatkan informasi dan wawasan, sehingga masyarakat dapat memahami secara mendalam tentang ekonomi kreatif serta manfaatnya bagi peningkatan pendapatannya. Bahkan menurut Saadah, Anwar sulili dan Bining Deserama (2011) menyebutkan bahwa pemahaman masyarakat sebelum mendapatkan penyuluhan dengan sesudah mendapatkan penyuluhan mempengaruhi pemahamannya hingga $56 \%$. Keberhasilan penyuluh pertanian yang ditujukan dengan diterimanya ide baru berlanjut sampai digunakannya ide baru oleh masyarakat (fungsi pelaku utama) berlangsung dalam suatu sistem penyuluhan pertanian yang didalamnya ada beberapa fungsi yang dapat saling mempengaruhi yaitu 1) fungsi penelitian, 2) fungsi pengaturan, 3) fungsi pelayanan, dan 4) fungsi penyuluhan (Dayat, tanpa tahun). Berdasarkan fungsi tersebut kegiatan kita memiliki fungsi penyuluhan, ini tampak dari aktifitas masyarakat setempat, dengan mudah menerima pengetahuan baru dan berkeinginan mengimplementasikannya. Namun untuk memperoleh hasil yang lebih maksimal hal yang dapat dilakukan adalah diperlukan kegiatan lanjutan yang bersifat pendampingan masyarakat sehingga mereka terus bisa menekuni usaha yang akan dibuat.

Hambatan yang dihadapi pada kegiatan penyuluhan ini adalah sulitnya menyesuaikan jadwal karena kebanyakan warga masyarakat adalah petani dan nelayan yang aktivitas siang hari mereka bekerja, selain itu jarak tempuh dari kampus ke desa ini yang relative sangat jauh sehingga membutuhkan waktu yang cukup lama untuk dapat mencapai desa ini terutama pada tahap awal sebelum kegiatan penyuluhan. Namun demikian diharapkan kegiatan ini dapat terus dilakukan dengan melaksanakan kegiatan penyuluhan dan pelatihan teknis yang berkaitan dengan pengembangan usaha ekonomi kreatif masyarakat yang sudah ada.

\section{KESIMPULAN}

128. Buana Ilmu 
Kegiatan penyuluhan untuk penguatan ekonomi kreatif berbasis sumberdaya desa Tanjungpakis Kecamatan Pakisjaya Kabupaten Karawang dapat memberikan manfaat yang besar bagi masyarakat. Hal ini terlihat dari antusiasnya masyarakat dalam mengikuti kegiatan penyuluhan dan dari tanya jawab juga tampak bahwa masyarakat merasa termotivasi untuk mengembangkan kreatifitas usahanya, demikian juga masyarakat yang hanya mengandalkan pekerjaannya sebagai petani dan nelayan tampaknya cukup tertarik untuk mencoba memulai mengembankan usaha kreatifitasnya Sehingga kegiatan ini perlu dilakukan secara berkelanjutan.

\section{DAFTAR PUSTAKA}

Ashley, C. \& Carney, D. (1999) Sustainable Livelihoods:Lessons from early experience [Internet]. Available from: http://www.eldis.org/vfile/upload/1/docu ment/0902/DOC7388.pdf [Accessed 28 Dec 2012]

Departemen Perdagangan RI, 2008. Pengembangan Ekonomi Kreatif Indonesia 2025. Studi Industri Kreatif Indonesia. Jakarta.

Prabowo, Ari Satria, 2012. Ekologi Tanaman Sagu. Didownload tanggal 22 Agustus 2014 dari http://magicterangers.blogspot.com/2012/07/ekologitanaman-sagu.html

Rismayadi. Budi, 2017. Karawang Berkebun : buku panduan menciptakan lahan pekarangan anda menjadi kebun bergizi, ISBN 978-602-61494-0-4. FBIS Publishing (FBIS UBP Karawang), 2017.

Rismayadi, Budi. Mumun Maemunah, 2018. Creative Economy to Increase Community Revenue Based on Tourism Object, Medalsari Village, Pangkalan District Karawang Regency, Journal of Accounting, Business and Finance Research. Vol. 3, No. 1, pp. 28-35, 2018. ISSN: 2521-3830. DOI: 10.20448/2002.31.28.35.

Saadah, Anwar Sulili dan Bining Deserama (2011). Peran Penyuluhan Pertanian Terhadap Terhadap Pendapatan Petani, yang menerapkan system tanam jajar Legowo. Jurnal Agrisistem, Desember 2011, Vol 7 No. 2

Khodijah , T.Said Raza'i .2014. Penguatan Ekonomi kreatif berbasis sumberdaya desa di kelurahan Alai Kecamatan Ungar Kabupaten Karimun. Lembaga Penelitian dan Pengabdian Masyarakat Universitas Maritim Raja Ali Haji Tanjungpinang, di unduh pada alamat http://khodijahismail.com/wp-content/uploads/2015/08/Laporan-Kegiatan-Pengabdian-padaMasyarakat-20141.pdf bulan Maret 2018.

Karawang Dalam Angka, 2017. BPS Karawang, diakses pada alamat http://karawangkab.bps.go.id pada maret 2018

Katalog Kecamatan Karawang Dalam Angka 2017. BPS Karawang diakses pada alamat https://karawangkab.bps.go.id/publication/download.html?nrbvfeve=NWQ0MWJhM2E2NjQ5NzFl YjM3MmQ2ZjEw\&xzmn=aHR0cHM6Ly9rYXJhd2FuZ2thYi5icHMuZ28uaWQvcHVibGljYXRp b24vMjAxNy8wOS8yNi81ZDQxYmEzYTY2NDk3MWViMzcyZDZmMTAva2VjYW1hdGFuLX Bha2lzamF5YS1kYWxhbS1hbmdrYS0yMDE3Lmh0bWw\%3D\&twoadfnoarfeauf=MjAxOC0wM y0zMSAwODoxOTo1MQ\%3D\%3D pada Maret 2018 